\title{
Longer communicable period of COVID-19 infection in children: a retrospective study
}

\author{
Chang Wang ${ }^{1}$, Mengchun Jiang ${ }^{1}$, Jianlei $\mathrm{Lv}^{2}$, Qian Zuo ${ }^{2}$, Tianlong Huang ${ }^{1}$, Lizhi Zhou ${ }^{1}$, \\ Ya $\mathrm{Li}^{1}$, and Xiangyu Chen ${ }^{1}$ \\ ${ }^{1}$ Second Xiangya Hospital \\ ${ }^{2}$ First Hospital of Changsha
}

May 26, 2020

\begin{abstract}
Objectives: The clinical characteristics and outcomes of COVID-19 pneumonia in children are different with adults. We evaluated the clinic characteristics and communicable period of COVID-19 pneumonia in pediatric patients of Changsha, capital of Hunan province. Methods: This is a retrospective study. We enrolled all 12 COVID-19 pneumonia pediatric patients and 134 adult patients in the Public Healthy Medical Center of Changsha from 29th Jan. to 20th Feb. Final date of follow-up was 10th Mar. We analyzed the characteristics and communicable period communicable period of pediatric patients, compared the differences between the pediatric and adult patients. Results: Of the pediatric patients enrolled, the median age was 8.5 years old. Four (33.3\%) children were asymptomatic, but one had image changes. Fever 5(41.67\%) and cough $4(33.33 \%)$ were the most common symptoms at onset of illness. Leukopenia, ALT/AST, LDH, CRP and PCT elevation were significantly less than adults. Only six children (50\%) showed chest CT images changes. All patients were given antiviral drugs and supportive treatment. The estimated median communicable period was 15(8-17.75) days, which was significantly longer than adult patients $10(8-12)$ days $(\mathrm{P}=0.044)$. However, the clinic cause of adult patients was much severe than pediatric patients, including Leukopenia, CRP elevation, typical radiological changes, clinic classification, and supporting therapy. Conclusion: In summary, majority of pediatric patients have a mild clinic cause and longer communicable period than adult, so they may need a longer quarantine period likely to be a supper source of infection.
\end{abstract}

\section{Hosted file}

manuscript.doc available at https://authorea.com/users/326607/articles/454412-longercommunicable-period-of-covid-19-infection-in-children-a-retrospective-study

\section{Hosted file}

Table 1.docx available at https://authorea.com/users/326607/articles/454412-longercommunicable-period-of-covid-19-infection-in-children-a-retrospective-study

\section{Hosted file}

Table 2.docx available at https://authorea.com/users/326607/articles/454412-longercommunicable-period-of-covid-19-infection-in-children-a-retrospective-study

\section{Hosted file}

Table 3.docx available at https://authorea.com/users/326607/articles/454412-longercommunicable-period-of-covid-19-infection-in-children-a-retrospective-study

\section{Hosted file}


Figure 1.docx available at https://authorea.com/users/326607/articles/454412-longercommunicable-period-of-covid-19-infection-in-children-a-retrospective-study

\section{Hosted file}

Figure 2.docx available at https://authorea.com/users/326607/articles/454412-longercommunicable-period-of-covid-19-infection-in-children-a-retrospective-study 